\title{
Professional nurses as reflective clinical learning facilitators
}

Mary Chabell

M. Cur. RAU

Lecturer, RAU Nursing Department

\begin{abstract}
With the rapid changes taking place in the country, including the education system in general and nursing education in particular, the role of professional nurses as reflective clinical learning facilitators need to be re-visited in order to meet the changing health needs of the communtiy and to facilitate outcome-based nursing education and evidence-based quality nursing care. The purpose of this paper is to explore and describe the perceptions of professional nurses as reflective clinical learning facilitators in the clinical learning units, within the context of a specific health-care service in Gauteng. A phenomenological method using descriptive naive sketches was used to collect data from twenty professional nurses complying with certain inclusion criteria. A content analysis was performed and eight categories (main concepts) were identified in order of priority as follows: communication/collaboration; role-modelling; continuous assessment and evaluation; up-to-date knowledge; scientific approach; clinical teaching; management and professionalism. After a literature control was conducted, these main concepts were confirmed. It is recommended that a model to facilitate reflective thinking in clinical nursing education be developed, using these concepts as basis for the provisional conceptual framework.
\end{abstract}

\section{UITTREKSEL}

Met die vinnige veranderinge wat tans in die land plaasvind, insluitende die veranderinge in die onderwysstelsel oor die algemeen en in verpleegonderwys in besonder, moet die rol van die professionele verpleegkundige as reflektiewe kliniese leerfasiliteerder in oënskou geneem word om in die veranderende gesondheidsbehoeftes van die gemeenskap te voldoen en om uitkomsgebaseerde verpleegonderwys - insluitende gehalteverpleging - te fasiliteer. Die doel met hierdie artikel is om die persepsies van professionele verpleegkundiges as reflektiewe kliniese leerfasiliteerders in die kliniese verplegingseenhede, binne die konteks van ' $n$ spesiefieke gesondheidsdiens in Gauteng, te verken en te beskryf. ' $n$ Fenomenologiese navorsingsontwerp is gebruik, met beskrywende naïewe sketse as metode vir dataversameling, deur twintig professionele verpleegkundiges wat aan die insluitingskriteria voldoen het. ' $n$ Inhoudsontleding is uitgevoer en agt kategorieë (hoofkonsepte) is geiddentifiseer en is, volgens prioriteitsorde, soos volg: kommunikasie/samewerking; rolmodellering; deurlopende beraming en evaluering; op-datum-kennis; wetenskaplike benadering; kliniese onderrig; bestuur en professionalisme. Hierdie konsepte is deur middel van ' $n$ literatuurkontrole bevestig. Daar word aanbeveel dat ' $n$ model, vir die fasilitering van reflektiewe denke in kliniese verpleegonderwys, ontwikkel word met die benutting van hierdie konsepte as die basis van die voorlopige konseptuele raamwerk. 


\section{INTRODUCTION}

Reflective clinical learning facilitators in nursing education is required to ensure outcome-based nursing education and evidence-based quality nursing care. Many research reports in Nursing Science reveal the inadequate integration of theory and practice in the basic nursing programmes, both nationally and internationally (Mashaba, 1991:2). The effectiveness of the teaching role of nurse educators and clinical facilitators has been questioned for many years (Hinchliff, 1979:50).

At present education in general is under pressure from both external and internal factors in the country. With the rapid changes and pressures exerted for transformation resulting from the political, socio-economic, technological, constitutional, cultural, epidemiological and education changes, nursing education is also in the spotlight to change (Green Paper on Education and Training in South Africa, 1996).

The focus on transformation in nursing education is the development of a student nurse with reflective thinking poten- explore and describe the perceptions of professional nurses as reflective clinical learning facilitators within the context of a health service in Gauteng.

\section{TERMINOLOGY}

\section{Clinical learning facilitation}

Facilitation is a goal-directed and dynamic process in which participants (professional nurse and nursing student) interact in a clinical learning environment of genuine mutual respect, in order to learn through critical reflection within the clinical nursing education context.

\section{Reflective clinical learning}

Reflective clinical learning is the process of internally examining and exploring an issue of concern, triggerred by an experience, which creates and clarifies meaning in terms of self, and which result in a changed conceptual perspective (Boyd \& Fales, 1983:99).

\section{RESEARCH DESIGN AND METHOD}

An exploratory, descriptive, qualitative
The principles described by Tesch (in Creswell, 1994:155) were used for the descriptive content analysis of data collected. An external coder, also purposively selected, used a similar protocol for content analysis. A consensus discussion between the researcher and the external coder was arrived at with regard to the categories derived from data collected.

This was followed by a literature control and the results served as a basis for the conceptual framework utilised for the formulation of guidelines (to be presented in a follow-up article). Throughout the study, trustworthiness was ensured according to the method of Lincoln and Guba (1985) related to the four aspects of credibility, transferability, dependability and confirmability.

The following principles of trustworthiness are justified:

* prolonged engagement: the researcher and supervisor are both ex perienced educators and clinical nursing practitioners;

* triangulation by means of various sources (nursing practitioners and literature);

\section{It is, therefore, the responsibility of a reflective clinical learning facilitator to afford student nurses the opportunity to develop the ability to communicate freely and meaningfully}

tial to be able to render culture-specific/ sensitive and quality care to the community, based on the primary health care approach. The starting point would be a re-visit of the teaching role of professional nurses in the clinical learning unit. This teaching role has been influenced for decades by the authority- rule-bounded environment that re-inforces compliance with bureaucratic principles.

The dogmatic, traditional methods of teaching and learning have created an extensive theory-practice gap in the clinical learning of student nurses (Jones \& Brown, 1991:530).

It is, therefore, necessary to investigate the perceptions of professional nurses as reflective clinical learning facilitators, followed by the description of guidelines to empower them as reflective clinical learning facilitators, hence the research question arising from this problem is: What are the perceptions of professional nurses as reflective clinical learning facilitators in the clinical learning units within a particular health service in Gauteng?

The aim of this research is, therefore, to and contextual design was used. A phenomenological (objective) method using descriptive naive sketches was used to collect data from professional nurses. Giorgi (in Omery, 1983:57) maintains that this method requires that the researcher allows, without bias, the experience of participants to unfold as it exists.

Twenty professional nurses were purposively selected. Participants fulfilled the selection criteria of being in charge or a deputy with five or more years' of experience, working in clinical learning units where student nurses are allocated for their clinical learning practice in a specific health service in Gauteng. Written consent to participate in the research was obtained from participants.

Participants used a blank sheet to write on, on which the following central question appeared: What is your perception as a reflective clinical learning facilitator in the clinical learning units?

As participants were writing in a comfortable, noise-free conference room, the researcher made field notes to describe the dynamics and her impressions.
* an external, independent coder was used for the content analysis and consensus discussions on the main categories;

* member checking: interviews with related participants to validate the content of the naïve sketches, as well as the outcome of the content analysis;

* dense background information was provided to the participants prior to data collection;

* a dense description of the research process/method was given.

\section{DISCUSSION OF RESULTS}

A total of 20 professional nurses wrote their naive sketches and the following eight categories were identified with regard to the reflective clinical learning facilitator within the context of clinical nursing education: communication/collaboration; role modelling; continuous supervision; assessment and evaluation; up-to-date knowledge and skills; scientific approach; clinical teaching; management and professionalism (see table one). 
Table 1: Distribution of categories

\begin{tabular}{|l||l||c|}
\hline Main Category & Sub-Categorles & N \\
\hline Clinical Learning & * Collaboration/communication & 15 \\
& * Role modelling & 15 \\
& * Continuous supervision, \\
& assessment and evaluation & 12 \\
& * Up-to-date knowledge & 11 \\
& * Orientation & 9 \\
& * Scientific approach & 9 \\
& * Clinical teaching & 9 \\
& * Management & 7 \\
& * Professionalism & 7 \\
\hline
\end{tabular}

\section{Communication/collaboration}

The two concepts were used interchangeably. Participants emphasized the use of effective communication and collaboration as an important vehicle for the facilitation of clinical learning.

This was evidenced by the following direct quotations: "We need to communicate continuously and effectively with the nursing college with regard to students clinical requirements, scope covered at college and students' progress. There is no communication between the college and the ward sister presently."

"...hold regular meetings with staff members to have a common platform on which to discuss issues, decisions and solve problems together."

Participants maintained that effective communication and collaboration remain the mainstay of a reflective clinical learning facilitator. It is a vehicle towards achieving success in managing the student, the clinical environment and clinical learning.

The liason person between the college and the clinical learning units is necessary to facilitate communication with reference to student nurses' clinical learning requirements. Depending on the effectiveness of communication and collaboration, Gillies (1994:183) maintains that a communication climate may either facilitate or inhibit clinical learning.

In support, Weidenbach (1969:33) maintains that the ability to communicate meaningfully within the realities of a particular clinical area, adds a practical dimension to student learning.

It is, therefore, the responsibility of a reflective clinical learning facilitator to afford student nurses the opportunity to develop the ability to communicate freely and meaningfully (Wong \& Wong, 1987:507; Knox \& Morgan, 1985:25; Muller, 1995:16, 20; Cerinus, 1994: 36).

Meaningful communication leads to con- struction of new knowledge and meaning, and reflective clinical learning facilitators need to consider different approaches to clinical learning.

Klopper (1994, Monograph 2:35) suggests that the interpersonal context within which sense and meaning are constructed comprises dialogue, discourse and narratives to generate information continually. These strategies can only be used in a climate of openness (Muller, 1995:16) when students are autonomous.

It is necessary to hold regular meetings to create a platform where issues are debated, decisions made and problems solved. Gillies (1994:482) maintains that the head nurse should use a collaborative approach to conflict management, confronting conflict issues openly and developing a climate of trust, so that those in dispute can explore a full range of alternatives before selecting a solution that maximize benefits for all.

Muller (1995:16) concurs with Gillies (1994:482) when discussing participative management in that a climate of openness should be introduced to facilitate problem-solving by joint planning, consultation, consensus and negotiation. This encourages a healthy working environment.

Today, the profession is inundated with strikes which pose a challenge to reflective clinical learning facilitators in helping students to develop negotiation skills and to realise that strikes do not solve problems.

Clinical learning should mould student nurses into responsible professional adults. According to Weidenbach (1969:66), "... the road to learning is often a rocky one."

\section{Role modelling}

Role modelling was perceived by participants as one of the most important char- acteristics of a reflective clinical learning facilitator as evidenced by the following citation:

"We should be examplary in all aspects, that is academic, professional involvement, dress code, ethical, administration and management style because student nurses imitate their activities good or bad."

From the results it became clear that role modelling is an important characteristic of a reflective clinical learning facilitator, as student nurses will imitate their activities, whether they are good or bad.

This notion is supported by Barr (1980:49), who maintains that nursing personnel in the clinical learning units are primary role models whose attitudes, positive or negative, are quickly observed and imitated by students.

In the same vein, Barr (1980:49) gives a warning that negative learning is expensive as regards time, and it is also difficult to reverse.

In view of the above, it is important for reflective clinical learning facilitators to be cautious and, according to Murphy (1993:1189), open-minded, self-aware, analyse feelings, synthesize, evaluate and be motivated at all times in order to be effective role models to student nurses.

\section{Continuous supervislon}

Participants regarded continuous assessment and evaluation as an important aspect of a reflective clinical learning facilitator.

This became evident from the following quotation: "We, together with nurse educators, should jointly be involved with the continuous assessment and evaluation of students in the clinical learning units so that we can speak the same language."

Professional nurses also expressed the need to be involved in student clinical examinations as evaluators: "We ne日d to be involved in student's practical examination so as to be familiar with what is called OSCE: thereafter post evaluation conference are necessary to identify students' and evaluators' strength and weak nesses."

To determine whether clinical knowledge has been acquired, participants maintained that continuous assessment and evaluation is necessary. For effective assessment and evaluation to take place, participants also indicated that both the nurse educator and the reflective clinical learning facilitator should be involved in the evaluation of the student.

In support, Mellish (1980:123) maintains that nursing personnel should supervise, assess and evaluate student nurses in order to ascertain their 
strengths and weaknessess in their clinical performance.

Ramsden (in Klopper, 1994 Monograph $2: 20$ ) also states that valuable feedback on learners' work is essential for efficient and effective guidance. Participants concurred with this notion by suggesting that there should be post-evaluation conferences with student nurses to discuss strengths and weaknesses of students and evaluators.

Evaluation should not be seen as punishment but as part of the learning experience (Barr, 1980:49; Schweer, 1972:168/9; Reilly \& Oerman, 1985:297).

\section{Up-to-date knowledge and skills}

It became evident from the naïve sketches that there is a need for professional nurses to keep up to date with regard to clinical expertise and professional matters.

This was displayed by the citation: “...professional nurses must be competent and knowledgeable with contemporary issues in clinical practice, and the changing teaching role." In emphasizing the importance of up-to-date knowledge, the following quotation was made: "...many a times students do not ask questions because we the 'BAR ONE' professional nurses lack knowledge. This leads to professional nurses developing a negative attitude towards teaching and guiding students in the ward."

A reflective clinical learning facilitator cannot afford to remain aloof in this rapidly changing educational setting. Participants expressed the need to keep their knowledge up to date with reference to their teaching role in the clinical setting. According to didactic principles, the facilitator should possess expert knowledge in the practice area.

Long (in Klopper, 1994; Monograph 2:11) points out that learners recognise and accept the learning facilitator on the basis of his superior knowledge and skills, yet Gravett (in Klopper, 1994, monograph 2:11) urges reflective clinical learning facilitators to use reflective teaching strategies such as dialogue, debate, discourse and narrative in order to develop reflective thinking skills in clinical practice.

Participants also expressed the need to engage in staff-development programmes in order to update their knowledge and avoid the nickname 'BAR ONE' professional nurses by student nurses based on their lack of knowledge.

This leads to professional nurses losing confidence as reflective clinical learning facilitators and developing a negative attitude towards teaching students.

\section{Scientific approach}

Participants acknowledged the importance of using the nursing process as part of the problem-based approach to develop reflective thinking skills in clinical learning

This was displayed by the following citation: "Nursing process must be used to develop reflective thinking skills in clinical learning. Use clinical problems as stimulus aimed at problem-solving process."

As much as participants acknowledged the importance of using nursing process as part of the problem-based approach to develop reflective thinking skills in clinical learning, its effectiveness is presently under heavy criticism nationally and internationally. Yura and Walsh (1983) maintain that nursing process has served to guide, organize and direct nursing care.

This statement is supported by Pinnel and De Meness (in Lindsey \& Hartvick 1996:106). On the other hand, Skeet and Thompson (1985:15) maintain that, in its present form, the nursing process is seen as limiting the creativity of nursing practice. Nursing process has also been criticised for the predominance and influence of positivism, rationality and empiricism, as it emphasises science as a source of knowledge and minimises intuition. (Field in Vancoe, 1996:121).

The authors argue that this philosophical orientation is inappropriate because nursing commonly uses intuition as a way of knowing. Chenitz and Swanson (in Varcoe, 1996:122) maintain that the development of the nursing process is described as being deductive and not derived from actual nursing practice, therefore it does not capture what nurses actualiy do.

It is time consuming, loaded with jargon, superfluous and static (De la Cuesta in Varcoe 1996:122). However, Gordon and Field (in Varcoe, 1996:12) suggest that nursing process is useful to guide clinical practice. This calls for an urgent revisit of the refinement and effective use of the nursing process in clinical practice by reflective clinical learning facilitators to fulfill its intended purpose.

\section{Teaching in a clinical unit}

It became evident from the results that the teaching role of professional nurses in clinical learning units is important and irreplaceable.

Also, the importance of improving teaching methods was highlighted, as evidenced by the following quotations: "The teaching component of the professional nurses should be developed rather than diminished since they are in a suitable position to facilitate the learning of students in the clinical practice based on their 'real' expert knowlege and experience." "We need improved teaching methods to add on case studies, ward and nursing rounds, workbook, demonstrations and teachable moments in order to stimulate reflective thinking skills in clinical practice."

Professional nurses acknowledged that their teaching component in the clinical learning unit is important and irreplaceble. They also highlighted that their teaching component should be developed rather than diminished since they were in a suitable position to facilitate clinical learning based on their 'real' expert knowledge and experience.

The traditional teaching methods have proved to be ineffective in developing reflective thinking skills in clinical practice. Palmer et al. (1994:72) maintain that reflection needs to be analysed critically, interpreted and compared with other perspectives.

In support Schön (in Palmer et al 1994:72) maintains that ideas need to be shared, debated and that debriefing should be done after experience. Wong et al. (1995) advocates the keeping of reflective journals to record experiences immediately after they occur.

It is, therefore, important according to Palmer et al. (1994:72) that space for this type of learning be built into the clinical learning syllabus during working hours, when nurses can be given official time to write, discuss and debate their experiences with the mutual purpose of learning. It leaves the professional nurses to ponder on the issue of student status to facilitate their role as reflective clinical learning facilitators.

\section{Management}

Effective management skill were highlighted by participants as one of the important aspects of a reflective clinical learning facilitator, as evidenced by a quotation: "...the climate in the clinical unit can only be conducive to learning if we can use participative management in decision-making and problem solving, and if we can deal with obstacles that hamper learning in the clinical unit."

Participants identified effective management as being a pivotal aspect of a reflective clinical learning facilitator. Participants maintained that participative management in decision making and problem-solving is the cornerstone of clinical practice.

Since a reflective clinical learning facilitator is responsible for managing the student, the clinical area and clinical 
learning, it is important that all stakeholders in clinical learning, together with student nurses at all levels, be included in the decision-making and problem-solving of issues in the clinical practice.

Ramsden (in Klopper 1994, Monograph 2:21) maintains that the facilitator should establish a context in dynamic equilibrium that acknowledges the learner's need for self-direction characterised by freedom of speech, but there should be controlled informality and explicit aims. In the same vein, Ramsden emphasises that discipline remains important in maintaining equilibrium.

Reflective learning and discipline cannot be seperated. One aspect that was mentioned by participants was the maintanance of self-discipline by students and the removal of obstacles to clinical learning in the clinical practice. A reflective clinical learning facilitator is responsible for creating a climate conducive to learning. Barr (1980:49) maintains that, if the learning climate is positive, students will feel challenged by their learning.

This author identified some obstacles that exist in the clinical practice, such us overcrowding which prevents physical space for actual learning experience, lack of office space for tutorials, noise level and numerous activities taking place, as well as obsolete policies.

Ryan et al. (in Gray \& Pratt 1992:195) indicate that a lower staff:student ratio will facilitate learning. Ogier (1986:57) maintain that limited resources and personnel will create an obstacle to clinical learning. The reflective clinical learning facilitator is faced with challenges in providing effective management for clinical learning to take place.

\section{Professionalism}

Suprisingly, less emphasis was placed on the importance of professionalism as a characteristic of a reflective clinical learning facilitator.

However, one of the participants positively cited: "In as far as professionalism is concerned, the profession is dying a slow death. People come to nursing for employment, not as a calling."

Much less emphasis was placed on the importance of professionalism as one of the characteristics of the reflective clinical learning facilitator.

One of the participants expressed concern about the deteriorating image of the profession in the eyes of the consumers of health (community).

The reflective clinical learning facilitator has the responsibility to guide the student nurse to professional maturity. The

\section{...a lower staff:student ratio will facilitate learning...}

student nurse should accept responsibillity and accountability at an early stage of training, as clinical learning takes place in a complex, value-ridden clinical practice milieu, where legal and ethical consideration have to be noted.

Barr (1980:48) further maintains that the clinical practice should promote growth and protect the rights of all persons involved. The same notion is supported by Campbell (1994:1126, 1128); Rose (1994:1004, 1007) and SANA (1977).

\section{Concluding statements de- rived from the results}

Reflective clinical learning facilitators should consider the following features to facilitate the clinical learning, as identified by participants:

* Communication/collaboration skills to maintain a healthy interactive mode between student nurses and reflective clinical learning facilitators.

* Role modelling to display the educational, professional, academic and social role to enhance clinical learning.

* Meaningful supervision, assessment and evaluation to identify the strengths and weaknesses of both the student and the facilitator, with the aim to promote self-confidence amongst students.

* Up-to-date knowledge to be in line with the evolving changes in the teaching and practice of nursing.

* Orientation and staff-development programmes to facilitate clinical learning.

* The nursing process to be used creatively to stimulate reflective thinking in the clinical learning.

* Clinical teaching to create a clinical context conducive to learning, and use of the reflective teaching strategies that will encourage an integrated approach of theory and practice.

* Participative management in decisionmaking and problem-solving processes to facilitate clinical learning.

* Professionalism to display a high standard of professional practice that will enhance clinical learning.

\section{CONCLUSIONS AND RECOMMENDATIONS}

In this study, the perceptions of professional nurses as clinical learning facilitators were described and supported by literature. Once again, the teaching component of professional nurses in the clinical learning units cannot be replaced. Marson (1984:13) supports this notion. The following recommendations are made:

* that the effectiveness of the teaching component is researched with the aim of developing reflective methods of teaching in the clincial learning units;

* the described perceptions could be used to improve the practice and nursing education;

* the clarification of the concept: reflective thinking/reasoning within the context of clinical nursing education in South Africa:

* the development of a model to facilitate reflective thinking/reasoning in clinical nursing education in South Africa.

\section{CONCLUDING REMARKS}

The quest for nursing education is excellence in clinical practice.

The point of departure is to re-visit the role of the professional nurse as a reflective clinical learning facilitator to ensure outcome-based clinical nursing education and evidence-based quality nursing care. 


\section{References}

Barr, F. (1980): Are Your Students Positive about their Experience in the Clinical Area? The Canadian Nurse, October 1980: 45-48.

Boyd, E.M. \& Fayles, A.W. (1983): Reflective learning: key to learning from experience. Journal of Humanistic Psychology, 23 (2): 99-117.

Campbell, E. (1994): Learning to nurse in the clinical setting Journal of Advanced Nursing, 20: 1125-1131.

Cerinus, M. (1994): Preparing nurses for preceptorship. Nursing Standard, 8(36), June: 35.

Cresswell, J.W. (1994): Research Design: Qualitative and Quantitative Approach. London: Sage Publications.

Gillies, A.D. (1994): Nursing Management. A System Approach. London: W.B Saunders.

Gray, G. \& Pratt, R. (1992): Issues in Australian Nursing 3. London: Churchill Livingstone.

Green Paper on Education and Training in South Africa. (1996).

Hinchliff, S.M. (1979): Teaching Clinical Nursing. London: Churchill Livingstone.

Jones, A,F. \& Brown, N. (1991): Critical thinking: Impact on Nursing Education. Journal of Advanced Nursing, 16: 529-533.

Klopper, H.C. (1994): The Learning Accompanist in Nursing Science. Johannesburg: Rand Afrikaans University. Monograph 1, 2 and 3.

Knox, J.E \& Morgan, J. (1985): Important Clinical teacher behaviours as percieved by University Nursing faculty, students and graduates. Journal of Advanced Nursing, 10: 25-30.

Lincoln, Y.S \& Guba, E.G. (1984): Naturalistic Inquiry. London: Sage.

Lindsey, E. \& Hartvick, G. (1996): Health-Promoting Nursing Practice: the demise of the Nursing Process? Journal of Advanced Nursing, 23: 106-112.

Marson, S.N. (1984): Developing the "Teaching" Role of the Ward Sister. Nursing Education Today. Long Group Ltd. : 1315.

Mashaba, G. (1991): Centenerary Conference. Bloemfontein
Mellish, J.M. (1980): Unit Teaching and Administration for nurses. Pretoria: Butterworths.

Muller, M.E. (1995): Participative Management in Health Care Service. Curationis, 18(1), March: 15-21.

Murphy, E.K. (1987): The Professional Status of Nursing: A view from courts. Nursing Outlook, Vol. 35 (1): 12-15.

Ogier, M. (1986): An 'Ideal' sister-seven year on. Nursing Times, January 29: 54-57.

Omery, A. (1983): The Functioning of Nursing Routines in Management of a Transient Workforce. Journal of Advanced Nursing, 14: 180-189.

Palmer et al. (1995): Reflective Practice in Nursing. Oxford: Blackwell Science.

Relly, D.E. \& Oerman, N.H. (1985): The Clinical Field: Its Use in Nursing Education. Norwalk: Appleton and Lange.

Rose, P. (1994): Nursing: an integration of art and science within the experience of the practitioner. Journal of Advanced Nursing, 20: 1004-1009.

Schweer, J.E . (1972): Creative teaching in clinical nursing. St. Louis: Mosby.

Skeet, M \& Thompson, R. (1985): Creative Nursing, Processive Care and More? Journal of Advanced Nursing, 10: 15-24.

South African Nursing Assoclation. (1977): Student Status: The Board's View Regarding Supernumerary Status of Student Nurses. Pretoria: SANA.

Varcoe, C. (1996): Disparagement of the Nursing Process: the new dogma? Journal of Advanced Nursing, 23: 120-125.

Weidenbach, E. (1969): Meeting the realities in clinical teaching. New York: Springer Publishing Company.

Wong, F.K.Y.; Kember, D.; Chung, L.Y.F. \& Yan, L. (1995): Assessing the level of student reflection from reflective journals. Journal of Advanced Nursing, 22: 48-57.

Wong, J \& Wong, S. (1987): Towards effective clinical teaching in Nursing. Journal of Advanced Nursing, 12: 505-513.

Yura, H \& Walsh, M. (1983): Human needs and the nursing process. New York: Appleton-Century-Crofts. 